REFERENCES

Exton-Smith, A. N. \& Stanton, B. R. (1965). Report of an Investigation into the Dietary of Elderly Women Living Alone. King Edward's Hospital Fund for London.

Horwitt, M. K. (1953). F. Am. diet. Ass. 29, 443 .

Horwitt, M. K., Rothwell, W. S. \& Kark, R. M. (1953). Fedn Proc. Fedn Am. Socs exp. Biol. 12, 417.

Madden, S. C. \& Whipple, G. H. (1940). Physiol. Req. 20, r94.

Ministry of Health (1964). Rep. publ. Hlth med. Subj. no. II I.

Picou, D. \& Waterlow, J. C. (I962). Clin. Sci. 22, 3.

Schulze, W. (1954). Int. Congr. Geront. IIt. London, p. 122.

Swendseid, M. E. \& Tuttle, S. G. (1961). Publs. natn. Res. Coun., Wash. no. 843.

Watkin, D. M. (1964). In Mammalian Protein Metabolism. Vol. 2, Ch. I7. [H. N. Munro and J. B. Allison, editors.] New Yorls: Academic Press Inc.

Whipple, G. H. \& Madden, S. C. (I944). Medicine, Baltimore 23,2 I 5.

Widdowson, E. M. \& Kennedy, G. C. (1962). Proc. R. Soc. B r56, 96.

Woodford-Williams, Alvarex, A. S., Webster, D., Landless, B. \& Dixon, M. P. (1964-5). Gerontologia ro, 86 .

\title{
Aspects of malnutrition in the elderly
}

\section{By J. Andrews, West Middlesex Hospital, Isleworth}

When considering malnutrition in the elderly it must not be forgotten that this subject includes overnutrition and of course faulty nutrition. As has been pointed out by Professor Ferguson Anderson fat elderly men are a rarity. One reason for this is probably the high incidence of coronary artery disease found in the obese.

Dr Durnin has discussed energy requirements and Dr Berry proteins. Minerals will be considered later. I will, therefore, concentrate on general problems of malnutrition and topics connected with vitamin $\mathrm{C}$, folic acid and iron.

The following quotations from the British Medical Association (1950) Committee on Nutrition are of interest. Besides wishing to draw attention to "The urgent need for further extensive study of human nutritional requirements' the Committee recommended 'The speediest possible extension ... of meals delivery services for old people' and wished the government to 'promote the organisation of special catering departments in hospitals ... who should be responsible for feeding arrangements at all stages'.

A considerable amount of knowledge has been accumulated during the intervening 18 years with regard to the purchase of food but not with regard to the true intake of individuals, let alone the individual range of nutritional needs. Interesting investigations into the effect of deprivation of individual nutrients for long periods have been carried out, for example those of Crandon (1940) on experimental scurvy and Herbert (1962) on deprivation of folic acid. As far as I know there has been no work on experimental dietary iron deficiency in man.

With regard to the severity and prevalence of malnutrition in the elderly there are, in essence, three schools of thought. Dr Geoffrey Taylor (I966) stated that he found 'classical signs of vitamin deficiences and malnutrition in patients of all ages and classes in Britain' but this is unproven. At the other end of the scale it is suggested 
that there is no problem among the elderly, and this may lead to public complacency before essential research has been carried out to justify it. My view is that gross malnutrition is uncommon but is occasionally found in groups which are particularly vulnerable. How much marginal malnutrition exists, which only comes to light when infection or traumata supervene, it is very difficult to assess. It is here that there is much lack of detailed research into individual nutrients, which, owing to its complicated nature, could perhaps best be carried out in university departments of geriatric medicine, nutrition or physiology.

\section{Conditions that render elderly people particularly vulnerable to nutritional deficiency}

Gross locomotor or central nervous system diseases. They may have great difficulty in physically obtaining food. If socially isolated and living in the top of tall buildings such as a Glasgow tenement, they are at a double disadvantage.

Mental disturbances, Every geriatric physician knows that a majority of acute confusional states in the elderly are due to treatable physical causes and psychiatrists believe that the incidence of depressive states in the elderly is underestimated. If either of these states is untreated, under adverse social conditions the patients are liable to become malnourished.

Poverty. There are many causes of poverty and there is no time to discuss this. However no one should pretend that poverty does not exist among the elderly and is not a contributory cause to malnutrition.

Living in institutions. Another important group of vulnerable people are the institutionalized, whether in hospitals or old persons' homes. For reasons probably largely due to institutional cooking and distribution of food, their vitamin $\mathrm{C}$ and folic acid intakes are lower than those of other elderly people in the community. Two points emerge: (a) the elderly have a lower tissue level of vitamin $\mathrm{C}$ and folic acid than younger age groups, and (b) the elderly in institutions have a lower level of these nutrients than the elderly in the community.

\section{Vitamin C}

There is no evidence as yet that vitamin $\mathrm{C}$ deficiency causes any clinical illness other than scurvy. 'Senile purpura' is not related to vitamin $\mathrm{C}$ deficiency. Tattersall \& Seville (1950) and Andrews \& Brook (1966) have confirmed this using different methods. The former used urinary excretion tests and the latter measured vitamin $\mathrm{C}$ concentration in the white cells. It is possible that 'sublingual petechia haemorrages' are in some way associated with vitamin C deficiency (Andrews, Brook \& Allen, I 966), and we are carrying out further work on this. Griffiths, Brocklehurst, Scott, Marks \& Blackley (1967) and Andrews \& Brook (1968) showed that although there is a positive correlation between plasma and leucocyte levels of vitamin C, for any individual plasma level the leucocyte level could vary tenfold. Therefore, to asses the tissue vitamin $\mathrm{C}$ status of an individual, plasma and whole blood estimations are unsuitable. Both Kataria, Rao \& Curtis (1965) and Andrews et al. (1966) have 
shown that leucocyte levels of elderly people living in old persons' homes and hospitals can be lower than those living at home. In the latter series, the patients living at home were outpatients referred by the family doctor and therefore were presumably more 'unwell' than those in welfare homes not under current medical investigation and treatment. Allen, Andrews \& Brook (I967) have also reported a sex difference in leucocyte vitamin $\mathrm{C}$ levels, the men having significantly lower levels.

\section{Folic acid}

A recent leader in the British Medical Journal (Anonymous, I967) stated that 'Addisonian pernicious anaemia is by far the most likely diagnosis in older patients with a megaloblastic anaemia'. Folic acid deficiency (currently thought to be at least partly of nutritional aetiology) is in my experience a more common, but not a dramatic, cause. It responds well to treatment. Dr P. D. Roberts, our haematologist, and I have noticed that reticulocyte responses of the order of $6 \%$ are not uncommon and that they are accompanied by the disappearance of macrocytosis and a rise of haemoglobin level to normal, in patients who originally had megaloblastic changes in the bone marrow, 'low' serum folic acid and normal serum vitamin $B_{12}$ levels. Girdwood, Thomson \& Williamson ( 1967 ) found that the serum folic acid levels in elderly people were lower when they were in hospital than when they were in their own homes. Likewise Hurdle (1967) found that sixteen patients at home had average levels of $9.4 \mathrm{ng} / \mathrm{ml}$ and ten hospital patients had an average level of $3.3 \mathrm{ng} / \mathrm{ml}$. Hurdle's two groups were not randomly selected. He found the intake of folic acid by young adults from their food was $225 \mathrm{ng} /$ day, by residents of an old persons' home $145 \mathrm{ng} /$ day and by elderly people in hospital ror $\mathrm{ng} /$ day. The serum folate levels of elderly patients in hospital for periods of roo days and upwards did not change. The folate eaten was thought to be only enough to maintain the existing folic acid state and not enough to correct any deficiency. He postulated that increased demands on the body's folate stores, such as chronic infection, might result in anaemia.

Lowenstein, Cantlie, Ramos \& Brunton (i 966), Cooper \& Lowenstein (i966) and Hoffbrand, Newcombe \& Mollin (1966) showed in scatter diagrams in their respective papers that, for any single serum folate level the red cell folate level could vary very substantially. A similar lack of relationship between individual serum and white cell ascorbic acid levels has been mentioned above. Therefore it appears that the investigation of serum folic acid is not suitable by itself for assessing tissue levels. A number of haematologists now agree that laboratories, when they plan to add folate estimations to their services, should in the future aim to estimate the red cell folate as well as the serum folate level. Hurdle (r967) carried out six jejunal biopsies on patients with 'low' serum folic acid levels and none showed any significant histological abnormality. This suggests perhaps that malabsorption may not be an important cause of 'low' serum folate levels in the elderly. It is still to be found out to what extent 'low' levels in the elderly are due to malnutrition 
and to what extent they indicate a senescent condition sometimes associated with malabsorption.

\section{Iron-deficiency anaemia}

It is difficult to assess how great a role malnutrition plays in the aetiology of iron-deficiency anaemia. It appears that the more extensively iron-deficiency anaemia is studied from the gastro-intestinal angle, the more often silent bleeding from the gut is found to be the likely cause of the iron deficiency. Will \& Groden (1965) studied fourteen middle-aged and elderly men with iron-deficiency anaemia, none of whom had peptic ulcers, neoplasms or positive occult blood in the faeces. Full barium studies were carried out on all but one. In eight of the patients, intestinal diverticulae were demonstrated. They stated that they did not think consistently negative haematest results necessarily excluded significant gastro-intestinal loss of blood. In spite of being unable to carry out detailed barium studies as extensively as did Will \& Groden (1965), we found in the West Middlesex Hospital (Andrews, Fairley \& Barker, 1967) that nineteen out of the forty-three elderly iron-deficient patients had evidence of gastro-intestinal bleeding of one kind or another. The impression gained is that the marrow stores of many elderly patients are often low or absent and that any slight gastro-intestinal bleeding tips the balance, often causing overt iron-deficiency anaemia. It is by no means certain that there are more poor absorbers of orally administered iron among the elderly, but, as iron-deficiency anaemia is so common, the total number of anaemic elderly poor absorbers may present a large problem. The relationship, if any, between folic acid deficiency and iron deficiency in the elderly is yet to be worked out.

\section{Research projects}

Although it is not my purpose to suggest detailed research programmes I thought it might be useful to give examples of the type of work I, as a clinician, think would enhance our knowledge of the subject.

An investigation into vitamin $C$ renal thresholds in the elderly. It is known that low levels of vitamin $\mathrm{C}$ found in the leucocytes in the elderly can be raised to the standard commonly found in healthy younger adults by giving relatively large doses of vitamin $\mathrm{C}$ orally. I have failed to find any reference in the literature concerning whether the renal threshold level of vitamin $\mathrm{C}$ changes with age and whether it differs between the sexes. Ahlborg (1946) carried out interesting work after the war in Uppsala on the excretion of ascorbic acid by the kidney. Very little excretion takes place with plasma levels of under $\mathrm{I} \cdot 7 \mathrm{mg} / 100 \mathrm{ml}$ and then there is a 'threshold zone' rather than a threshold level at plasma levels between $\mathrm{I} \cdot 7 \mathrm{mg} / \mathrm{I00} \mathrm{ml}$ and 2.5 $\mathrm{mg} / \mathrm{roO} \mathrm{ml}$. He emphasized that there was wide individual variation. This research was carried out on twenty-four young healthy students. For further work in this field it would be necessary to take frequent samples of blood and urine during the administration of large doses of vitamin $\mathrm{C}$. This procedure would have to continue 
until the concentration of vitamin $\mathrm{C}$ in the plasma ceased to rise. It is known that some subjects are difficult to saturate with vitamin C (Boscott $\&$ Cooke, I954). The biochemical variation in human requirements for vitamin $\mathrm{C}$, stressed by Ahlborg, has recently been emphasized by Williams \& Deason (1967) in a paper concerning animal studies.

An investigation regarding the significance and aetiology of low folate levels commonly found in the elderly. The presence and destruction of folate in foods is known to be very difficult to assess and therefore such an investigation as this would extend university departments considerably in carrying out detailed and accurate investigations. It would be necessary initially for a dietary survey to be made of the food actually consumed at home by elderly people. Base-line investigations probably required by haematologists would then be carried out which would include sternal marrow puncture, haemoglobin, assessment of a peripheral blood film, serum vitamin $B_{12}$, red cell and serum folate level and a Figlu test. The subjects then would have to continue on the same diet and then be given micro doses of folate. All the above-mentioned investigations would then be carried out again after the completion of folate supplementation to see what changes had taken place. In those subjects where the folate deficiency had not been corrected, investigations for intestinal malabsorption would have to be carried out, probably in a hospital gastro-enterological department.

It should be emphasized that the biochemical findings mentioned with regard to vitamin $\mathrm{C}$ and folic acid do not prove that the elderly are suffering from any deficiency disease, but highlight the need for further research. From the available evidence I now feel that supplementation should not be carried out on a large scale until further work is done concerning the nature of these low values. These research programmes should not be postponed as any supplementation found necessary could then be undertaken without delay.

It is very important for research workers to carry out these types of investigation in close association with geriatric physicians in order that their programmes can be planned to give as much information as possible. The experience of clinicians is of great help in judging the significance of the large number of subjects who cannot be included in any nutritional study. Exton-Smith \& Stanton (1965) found that perhaps $20 \%$ in their Kings Fund Survey either refused to take part or were too confused or had to be excluded for other reasons. This obviously may be of considerable significance.

Finally, may I suggest that we need more nutritional research on human beings, of a kind which relates clinical observations and biochemical measurements with assessments of true dietary intake and that this will be most productive if it is possible to concentrate on a single nutrient at a time.

\section{REFERENCES}

Ahlborg, N. G. (1946). Acta physiol. scand. 12, Suppl. 36.

Allen, M. A., Andrews, J. \& Brook, M. (1967). Nutrition, Lond. 2I, p. 136.

Andrews, J. \& Brook, M. (1966). Lancet i, 1350 . 
Andrews, J. \& Brook, M. (r968). Geront. clin. 2, 28.

Andrews, J., Brook, M. \& Allen, M. A. (I966). Geront. clin. 8, 257.

Andrews, J., Fairley, A. \& Barker, R. (1967). Scott. med. \%. 12, 208.

Anonymous (1967). Br.med.7. ii, 652 .

Boscott, R. J. \& Cooke, W. T. (1954). Q. $f l$ Med. 23, 307.

British Medical Association (1950). Report of the Committee on Nutrition. London: British Medical Association.

Cooper, B. A. \& Lowenstein, L. (I g66). Br. F. Haemat. 12, 283.

Crandon, J. H. (1940). New Engl. F. Med. 223, I0.

Exton-Smith, A. N. \& Stanton, B. R. (1965). Report of an Investigation into the Dietary of Elderly Women Living Alone. King Edward's Hospital Fund for London.

Girdwood, R. H., Thomson, A. D. \& Williamson, J. (1967). Br. med. F. ii, 670.

Griffiths, L. L., Brocklehurst, J. C., Scott, D. L., Marks, J. \& Blackley, J. (1967). Geront. clin. 9, 1. Herbert, V. (1962). Trans. Ass. Am. Physns 75, 307.

Hoffbrand, A. V., Newcombe, B. F. A. \& Mollin, D. L. (1966). F. clin. Path. r9, 17.

Hurdle, A. D. F. (1967). MD Thesis, Lniversity of London.

Kataria, M. S., Rao, D. B. \& Curtis, R. C. (1965). Geront. clin. 7, I89.

Lowenstein, L., Cantlie, G., Ramos, O. \& Brunton, L. (rg66). Can. med. Ass. F. 95, 797.

Tattersall, R. N. \& Seville, R. (1950). Q. fl Med. I9, I5I.

Taylor, G. (I 966). Lancet i, 926 .

Will, G. \& Groden, B. (1965). Scott. med. F. ro, 2 r.

Williams, R. J. \& Deason, G. (1967). Proc. natn. Acad. Sci U.S.A. 57, 6.

\section{Mineral metabolism in relation to ageing}

By D. A. Smith and I. Harrison, University Department of Medicine, Gardiner Institute, Western Infirmary, Glasgow, $W \mathrm{I}$, B. E. C. Nordin, MRC Mineral Metabolism Research Unit, Leeds General Infirmary, Leeds, and J. MACGREGor and M. JoRDan, Strathclyde University, George Street, Glasgow

Osteoporosis is a common condition, occurring more frequently in women than in men. It is especially common in women after the onset of the menopause. Beck \& Nordin ( 1960 ) reported osteoporosis in $12 \%$ of males and $23 \%$ of females dying in the Western Infirmary, Glasgow. Collins (1959) in a similar study reported an incidence of $8 \%$ in men and $18 \%$ in women over the age of 40 dying in the General Infirmary, Leeds.

Albright, Burnett, Cope \& Parsons (194I) and Albright, Smith \& Richardson (1941) from a study of osteoporosis in post-menopausal women, and women with Cushing's syndrome, suggested that the primary defect in osteoporosis was a failure in the synthesis of bone matrix. Nordin (1958, I960) suggested that osteoporosis in man might result from prolonged negative calcium balance.

It has been shown (Light \& Frey, I 94I; Greaves, Scott \& Scott, I959; Harrison $\&$ Fraser, I960) that a variety of laboratory animals fed on a low-calcium diet, but with adequate vitamin $\mathrm{D}$ and phosphorus, developed osteoporosis. Jowsey \& Gershon-Cohen (1964) confirmed these findings in cats. They also demonstrated that cats made osteoporotic with a low-calcium diet, and then given supplementary calcium, showed an increase in bone density. That a positive calcium balance can be produced in osteoporotic patients by feeding supplementary calcium has been reported by a number of authors (Owen, Irving \& Lyall, I940; Anderson, 1950; 